\title{
The rise of ecosystem ecology and its applications to environmental challenges
}

\author{
R. G. Woodmansee ${ }^{1}$ and S. R. Woodmansee ${ }^{a}$ \\ ${ }^{1}$ Natural Resource Ecology Lab., Colorado State University, Fort Collins, CO, USA \\ a formerly at: School of Social Work, Colorado State University, Fort Collins, CO, USA
}

Correspondence to: R. G. Woodmansee (bobw@ colostate.edu)

Received: 29 August 2015 - Revised: 28 October 2015 - Accepted: 29 October 2015 - Published: 13 November 2015

\section{Introduction}

Before the 1970s, different disciplines had their own narrow perspectives of what ecologists and natural resource managers now call "ecosystems" and landscapes. For example, in these earlier days ecologists studied and measured things they could see, touch, count, weigh, or map. Ecologists speculated about plant succession and animal dynamics. Rangeland and pasture scientists and managers were concerned with forage and animal production. Foresters studied board feet (or meters) of timber, tree reproduction, and harvesting techniques from forest stands. Hydrologists studied millimeters of precipitation, water yield from watersheds, and the effects of various manipulations on water yield. Each of these disciplines mostly measured livings things above ground or water. Ecosystems were viewed as "black boxes", if recognized at all. These disciplinary perspectives or "silo" views of systems meant little collaboration among scientific specialties.

Ecology as a discipline was changing during the 1950s and 1960s. E. P. Odum and his brother H. T. Odum were beginning to conceptualize energy flow in "ecosystems", and H. T. Odum was formulating early ideas about "systems ecology" (Odum, 1971). F. H. Bormann and G. E. Likens were formulating ideas about forested watersheds as "ecosystems" (Likens et al., 1977). This was the same period when "systems theory" was being developed by von Bertalanffy (1968), Forrester (1968), George van Dyne, Bernard Patten, Jerry Olson (Coleman, 2010), and others. The latter three introduced a new scientific paradigm: systems ecology (systems ecology is an interdisciplinary field of ecology, taking a holistic approach to the study of ecological systems). It can be seen as an application of general systems theory to ecology that contributed heavily to ecosystem science as we know it to- day (Fig. 1). Also, in the late 1960s and early 1970s period, a new public and institutional awareness of compelling environmental problems was emerging worldwide. The need for interdisciplinary approaches to problem solving was becoming recognized. The stage was set for the initiation of the new problem-solving paradigm, ecosystem science - the right science at the right time.

\section{Philosophy of science and theory of systems}

The theoretical basis of ecosystem science, the new paradigm, is the systems approach, plus systems analysis, plus ecosystems, called systems ecology (Fig. 1). The philosophy emphasizes a holistic view of ecological systems. It embraces both inductive and deductive reasoning. It emphasizes the integration of information and synthesis of ideas and concepts from that information, from original research when necessary, and from simulation modeling experiments and activities.

The philosophy and theory were formally put to the test when the National Science Foundation funded (in the USA) the International Biological Program. One of the significant tests of the philosophy and theory was the development of working simulation models such as the Grassland Ecosystem Model (ELM), and scientific methodology needed to develop the models (Innis, 1978).

\section{Methodology for conducting research about real-world complex problems}

Among the contributions of ecosystem science are several powerful methodologies for conducting research. Ecosystem science focuses on real-world, complex problems. It emphasizes integration and synthesis of knowledge in contrast to 


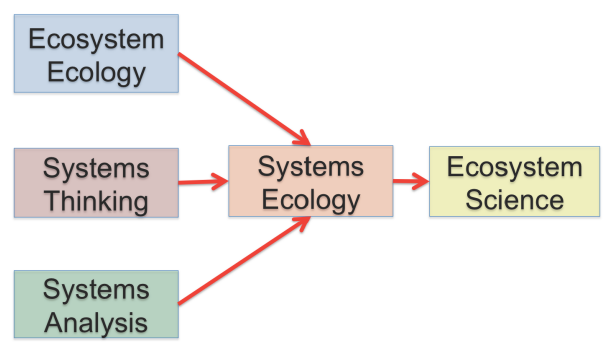

Figure 1. The relationship of ecology and systems science to ecosystem science.

focusing on reductionist research. Ecosystem science emphasizes processes and controls of processes in determining the functioning of ecosystems. Modeling, field studies, and laboratory research are integrated in the application of the science. Team research and collaboration with individuals and institutions throughout the world are a hallmark of the science. We might call this type of collaboration the "globalization of collaboration". Additionally, new organizational structures are incorporated into "centers of excellence" to coordinate unprecedented levels of funding and complex human resource management.

\section{Warehouse of peer reviewed scientific knowledge}

Ecosystem science has created a vast warehouse of knowledge. Some important concepts that have emerged out of ecosystem science have greatly improved our understanding of how ecosystems and societies interact. Some of these concepts are (1) the integration of ecology, soil science, hydrologic science, atmospheric science, and social/cultural sciences; (2) modeling/field studies/laboratory research being integrated; (3) C, N, P, S, $\mathrm{H}_{2} \mathrm{O}$ cycles - structures and dynamics being solved and modeled; (4) biogeochemical cycles being integrated; (5) belowground ecosystems/food webs; (6) plant and animal interactions being recognized; (7) ecological hierarchies in time and space being understood; and (8) the establishment of humans as ecosystem components. The influence of ecosystem science on environmental and natural resource management - such as grazing land and agricultural ecosystem management, acceptance of the importance of biodiversity, forest health, ecosystem-social interactions, and "collaborative ecosystem management" - has been profound. Many answers exist to important problems, and more research may not be needed to solve some problems because of the existing warehouse of knowledge.

\section{Future needs and challenges}

Ecosystem science anticipates future needs and challenges by recognizing environmental and societal problems often before the public or decision makers recognize them. A few important topics facing humanity which require ecosystem science (transdisciplinary and collaborative science incorporating field, laboratory, and modeling studies and extensive integration and synthesis activities at multiple scales) are food security; natural resource security; human population dynamics and consequences; invasive species; land-wateratmosphere exchanges and impacts; ecosystem resilience, adaptation, and sustainability; and global connections of all of the above. Reviewing old data and revisiting models may provide direction and point out areas for further scientific study.

New challenges facing ecosystem science are innovative methods of public education and including the immense resources and capabilities of online distance education for people in remote locations. The public includes politicians and their staffs, land and water managers, teachers, government agencies' staffs, nongovernmental organization staffs, and community leaders. A challenge in the area of public awareness is to inform citizens and decision-makers about the "warehouse of knowledge" and provide access to it. Ecologists need to partner with political scientists, marketing professionals, and psychologists to explore new ways of communicating our science to the public, and ecologists need to push back against anti-science forces as described in a recent National Geographic article, "The Age of Disbelief" (Achenbach, 2015). Ecologists and ecosystem scientists need to find new ways to communicate with policy and decision makers and citizens locally, regionally, nationally, and globally. To do this they will need to partner with business people, marketing professionals, educational psychologists, and communication specialists using modern communication skills and digital technology.

Edited by: D. Montesinos

Reviewed by: D. Swift and one anonymous referee

\section{References}

Achenbach, J.: The Age of Disbeleif, Nat. Geo., 227, 30-47, 2015. Coleman, D. C.: Big Ecology, Univ. California Press, Berkeley, 248 pp., 2010.

Forrester, J. W.: Principles of Systems, Wright-Allen Press, Cambridge, Mass., 387 pp., 1968.

Innis, G. S. (Ed): Grassland Simulation Model, Springer-Verlag, New York, 298 pp., 1978.

Likens, G. E., Bormann, F. H., Pierce, R. S., Eaton, J. S., and Johnson, N. M: Biogeochemistry of a Forested Ecosystem, SpringerVerlag, New York, 208 pp., 1977.

Odum, E. P.: Fundamentals of Ecology, Saunders, Philadelphia, 3rd edition, 574 pp., 1971.

von Bertalanffy, L.: General Systems Theory, George Braziller, New York, 296 pp., 1968. 